\title{
Does Arterial Stiffness Increase in Patients with Surgical Early Menopause?
}

\section{Cerrahi Erken Menopoz Geçiren Hastalarda Damar Sertliği Artar mı?}

\author{
Murat AKÇAY ${ }^{1} \mathbb{D}$, Metin ÇOKSEViM ${ }^{1} \mathbb{D}$, Ömer GEDiKLi ${ }^{1} \mathbb{D}$, Hasan ULUBAŞOĞLU ${ }^{2} \mathbb{D}$, Özcan YILMAZ ${ }^{1}$ (D)
}

\author{
${ }^{1}$ Department of Cardiology, Faculty of Medicine, Ondokuz Mayis University, Samsun,TURKEY \\ ${ }^{2}$ Clinic of Obstetrics and Gynecology, Samsun Education and Research Hospital, University of Health Sciences, Samsun, \\ TURKEY
}

\section{Abstract}

Background: Surgical early menopause is early menopause due to medical reasons rather than the natural aging process. Pulse wave velocity (PWV) and augmentation index (Alx) are simple and non-invasive parameters for assessment of arterial stiffness. The aim of this study investigated the arterial stiffness in the surgical early menopause patients.

Materials and Methods: We included 40 patients with surgical early menopause and 40 healthy controls for the study. The patients' arterial stiffness and hemodynamic parameters were measured with Mobil-O-Graph NG (IEM $\mathrm{GmbH}$, Stolberg, Germany) 24-hour ambulatory blood pressure monitor arteriography.

Results: There was no difference between the groups in baseline demographic, laboratory, and echocardiographic parameters except ejection fraction, glucose, and ALT values. In patients with surgical early menopause $(n=40)$, the etiology was malignancy in $27(67.5 \%)$, myoma in $11(27.5 \%)$ and bleeding in $2(5 \%)$ patients. PWV was significantly higher in the early menopause group $(6.5 \mathrm{~m} / \mathrm{s},(4.7-8.2)$ versus $5.6 \mathrm{~m} / \mathrm{s},(4.5-9.0 \mathrm{~m} / \mathrm{s}) ; \mathrm{P}<0.001)$, but there was no statistically significant difference in Alx (28.3 $\pm 10.9 \%$ versus $27.4 \pm 9.0 \% ; P=0.69)$. Also, there was no statistically significant difference in terms of cardiac hemodynamic parameters and central aortic pressures. Conclusions: Arterial stiffness is significantly increased in surgical early menopause patients compared with healthy subjects independent of other risk factors.

Key Words: Arterial stiffness, Pulse-wave velocity (PWV), Surgical early menopause

öz.

Amaç: Cerrahi erken menopoz, doğal yaşlanma sürecinden ziyade tıbbi nedenlerle meydana gelen erken menopozdur. Nabız dalga hızı (NDH) ve büyütme indeksi (Augmentasyon indeksi, Alx), arteryel sertliğin değerlendirilmesi için basit ve invazif olmayan parametrelerdir. Bu çalışmanın amacı, cerrahi erken menopoz hastalarında arteryel sertliği araştırmaktır.

Materyal ve Metod: Çalışmaya cerrahi erken menopozlu 40 hasta ve 40 sağlıklı kontrol dahil edildi. Hastaların arter sertliği ve hemodinamik parametreleri, Mobil-O-Graph NG (IEM GmbH, Stolberg, Almanya) 24 saatlik ambulatuvar kan basıncı monitör arteriyografisi ile ölçüldü.

Bulgular: Başlangıç demografik, laboratuvar ve ekokardiyografik parametrelerde ejeksiyon fraksiyonu, glukoz ve ALT değeri dışında gruplar arasında fark yoktu. Cerrahi erken menopozlu hastalarda ( $n=40$ ) etiyoloji değerlendirildiğinde 27 hastada (\% 67.5) malignite, 11 hastada (\%27.5) miyom ve 2 hastada (\%5) kanama idi. Nabız dalga hızı (NDH), erken menopoz grubunda $\left(6.5 \mathrm{~m} / \mathrm{s},(4,7-8,2) 5.6 \mathrm{~m} / \mathrm{s}^{\prime} y e(4,5-9,0 \mathrm{~m} / \mathrm{s})\right.$ karşı anlamlı olarak daha

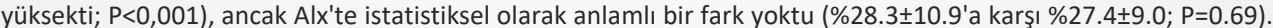
Ayrıca kardiyak hemodinamik parametreler ve santral aort basınçları açısından istatistiksel olarak anlamlı bir fark yoktu.

Sonuç: Cerrahi erken menopoz hastalarında arteryel sertlik, diğer risk faktörlerinden bağımsız olarak sağlıklı bireylerle karşılaştırıldığında önemli ölçüde artmıştır.

Anahtar kelimeler: Arteryel sertlik, Nabız dalga hızı, Cerrahi erken menopoz
Sorumlu Yazar/Corresponding Author

Dr. Murat AKCAY

Department of Cardiology, Ondokuz Mayis University, Kurupelit Campus, 55139, Atakum/ Samsun, TURKEY

E-mail: drmuratakcay@hotmail.com

Geliş tarihi / Received: 07.06.2021

Kabul tarihi / Accepted: 06.07.2021

DOI: 10.35440/hutfd.948505

The manuscript has not been published or presented by another journal. But, our article abstract has been accepted for poster presentation at ESC Congress 2020. "Abstract No: 89108- Does arterial stiffness increase in patients with early surgical menopause?" and published as "Does arterial stiffness increase in patients with early surgical menopause? M Akcay, M Coksevim, O Gedikli, $H$ Ulubasoglu, O Yilmaz. European Heart Journal, Volume 41, Issue Supplement_2, November 2020 ehaa946.3182

Published: 25 November 2020 ". 


\section{Introduction}

Menopause is a physiological condition in women and a part of the natural aging course (1). The incidence of cardiovascular disease (CVD) is lower in premenopausal women, but it cumulatively increases after the menopause, especially after surgical menopause (2). A lot of evidence strongly supports the role of estrogen in reducing a woman's risk of developing cardiovascular disease (1). The cardiovascular changes often occur asymptomatic during the menopausal transition; however, symptom and frequency of atherosclerotic diseases increase postmenopausal period (2). On the contrary, there is no premenopausal transition period in women undergoing surgical menopause. The surgical removal of the ovaries results in the discontinuation of sudden hormone production, which has adverse effects on many organs and system, particularly the cardiovascular system $(1,2)$.

Arterial stiffness is a marker of endothelial dysfunction. It develops from dynamic and complex interactions in the changes of cellular and structural elements in the vessel wall. The previous studies have demonstrated that arterial stiffness is a marker and prognostic factor for hypertension, chronic renal failure, stroke, dementia, heart failure, acute coronary syndromes, and especially atherosclerotic diseases $(3,4)$. The pulse wave velocity (PWV) and augmentation index (Alx) are easily measurable, non-invasive parameters and used to evaluate arterial stiffness. PWV is also considered as gold standard method for measuring arterial stiffness (3-5).

In this study, we aimed to investigate arterial stiffness using Mobil-O-Graph NG (IEM GmbH, Stolberg, Germany) 24-hour ambulatory blood pressure monitor arteriography in the surgical early menopausal patients.

\section{Materials and Methods}

\section{Study protocol}

The present study was planned cross-sectional and observational study. We included 40 patients with surgical early menopause and 40 healthy controls for the study. Patients who entered surgical menopause for various reasons in the medical faculty of obstetrics and gynecology clinic, were scanned retrospectively from the automation system and the patients were called to the outpatient clinic. The control group consisted of female patients of similar age who applied to the obstetrics and gynecology outpatient clinic with different complaints. All patients' age, body weight, height, cardiovascular risk factors, current medications and other systemic diseases were recorded. Also, the surgical early menopause duration and cause were recorded. The exclusion criteria were accepted as surgical menopause duration less than a year, ongoing estrogen replacement therapy, history of chemotherapeutic drug using, improper measurement of blood pressure, history of coronary artery disease, heart failure and cardiomyopathy.
All patients were informed about the study and gave written consent. The protocol was accepted by the ethics committee of Faculty of Medicine, Ondokuz Mayis University (No: 2017/455) and adhered to the Declaration of Helsinki.

\section{Measurement of arterial stiffness}

Mobil-O-Graph NG (IEM GmbH, Stolberg, Germany) 24hour ambulatory blood pressure monitor arteriography was used to measurement of arterial stiffness and cardiovascular hemodynamic parameters. The measurements were taken from brachial artery with a suitable size cuff in the sitting position. The measurements were performed in a silent, heat-controlled room $\left(22-24^{\circ} \mathrm{C}\right)$, in the early morning time and avoided from eating, or drinking alcohol, coffee or tea for at least before 12 hours. The device inflated the cuff automatically up to at least $35 \mathrm{mmHg}$ above the measured pressure value until no blood flow through the brachial artery. The blood flow was cut off as a result of occlusion by the brachial artery during the measurement period of a maximum of $20 \mathrm{sec}$. At the point where blood flow was cut off, a membrane was formed in the brachial artery at the upper edge of the inflated cuff. The waves generated by the central pressure changes described above were detected and augmented by the cuff with sensitive pressure sensors at this membrane level and then transferred to the device's dedicated tonometer. The waves recorded by tonometry and evaluated after uploading to HMS Client Server $5.1^{\circ}$ software. The measurement validation of this device about the arterial stiffness and hemodynamic parameters was demonstrated with invasive and non-invasive methods in the previous studies (6-8). The systolic blood pressure (SBP), diastolic blood pressure (DBP), mean arterial pressure (MAP), pulse pressure (PP), central systolic blood pressure (cSBP), central diastolic blood pressure (cDBP), peripheral vascular resistance (PVR), pulse wave velocity (PWV), augmentation index (AIX), and cardiac output (CO) parameters were recorded with this device (Fig. 1).

\section{Echocardiography}

The echocardiographic evaluation was performed in the left lateral decubitus position from standard acoustics views with Vivid 7 device (GE Medical System, Horten, Norway; $3.5-\mathrm{MHz}$ phased array transducer). The left ventricle end-diastolic and end-systolic dimensions, interventricular septum, and posterior wall thickness were measured in parasternal long-axis view. Ejection fraction was calculated by modified Simpson method. M-mode, two dimensional (2-D), Doppler and colored Doppler echocardiographic parameters of all patients were obtained and evaluated according to American Society of Echocardiography standards. 


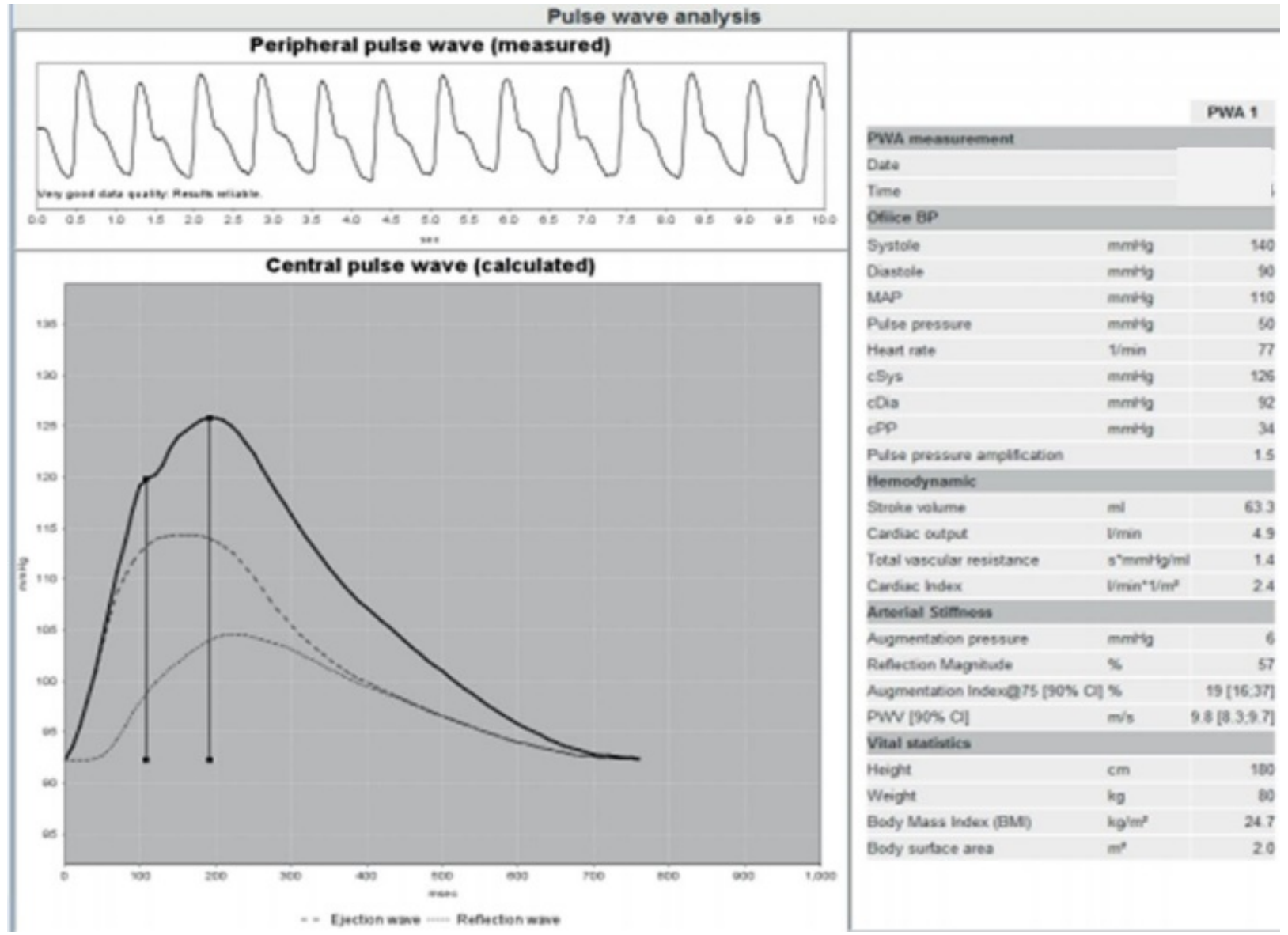

Figure 1. Basic parameters in the pulse wave record analysis with Mobil-O-Graph NG (IEM GmbH, Stolberg, Germany) 24-hour ambulatory blood pressure monitor arteriography.

\section{Statistical analysis}

The research data was uploaded to a computer and evaluated via "SPSS (Statistical Package for Social Sciences) for Windows 20.0 (SPSS Inc, Chicago, IL)". The Shapiro-Wilk test was used to determine the normality of distribution of continuous variables. Categorical variables were represented as numbers and percentages, continuous variables were represented as the mean \pm SD when normal distribution was present and as median (minimum-maximum) if the variables revealed non-normal distribution. Pearson's Chi-square test and Fisher's exact test were used to assess categorical variables. To determine of statistically significant differences between two independent groups, if the variables unsuitable for normal distribution, Mann-Whitney's U-test was used; if the variables suitable, Student's t-test was used. A $P$ value of $<0.05$ was accepted as statistically significant.

\section{Results}

The study included 40 surgical early menopause patients and 40 control subjects with similar clinical demographic characteristics. Total abdominal hysterectomy and bilateral salpingo-oophorectomy (TAH-BSO) operation in the surgical early menopause patients were performed due to malignancy or a mass suspicious to be malignant ( $n=27$, $67.5 \%)$, myoma ( $n=11,27.5 \%$ ) and bleeding ( $n=2,5 \%)$. The surgical early menopause duration was median 20 month (minimum 14 month, maximum 48 month). There were no statistically significant differences $(P>0.05)$ between the surgical early menopause and control groups, in terms of age and body mass index (BMI), smoking status, the presence of hypertension, and diabetes mellitus. The baseline descriptive characteristics were presented in Table 1.

Ejection fraction values were significantly lower in the early menopause group ( $P=0.008)$. Other echocardiographic and baseline laboratory parameters were found similar in both groups ( $P>0.05)$. The glucose and alanine transaminase $(A L T)$ values were significantly higher in the surgical early menopause group $(P=0.012$ and $P=0.013$, respectively) (Table 2 ). The heart rate and cardiac output were significantly high in the early menopause group compared to the control group ( $\mathrm{P}=0.008 ; 0.040$, respectively) (Table 3). On the other hand, there were no statistically significant differences in terms of systolic, diastolic, mean blood pressure, pulse pressure, central systolic and diastolic blood pressure, and peripheral vascular resistance $(P$ $>0.05)$. Pulse wave velocity (PWV) was significantly higher 
in the surgical early menopause group compared to control group $(6.5 \mathrm{~m} / \mathrm{s},(4.7-8.2 \mathrm{~m} / \mathrm{s})$ versus $5.6 \mathrm{~m} / \mathrm{s},(4.5-9.0$ $\mathrm{m} / \mathrm{s}) ; \mathrm{P}<0.001)$, but there were no significant differences in terms of augmentation index $(28.3 \pm 10.9 \%$ versus 27.4 $\pm 9.0 \%$; $P=0.69$ ) (Table 2).

Table 1. Distribution of baseline clinical, laboratory and basic echocardiographic parameters between surgical early menopause and control groups

\begin{tabular}{|c|c|c|c|}
\hline Variable & $\begin{array}{c}\text { Surgical early menopause group }(n=40) \\
\text { Mean } \pm \text { SD } \\
\text { Median (IQR) * }\end{array}$ & $\begin{array}{l}\text { Control group } \\
\quad(n=40) \\
\text { Mean } \pm \text { SD } \\
\text { Median (IQR) * }\end{array}$ & $P$ value \\
\hline Age (year) & $43.7 \pm 5.6$ & $41.8 \pm 6.1$ & 0.167 \\
\hline BMI $\left(\mathrm{kg} / \mathrm{m}^{2}\right)$ & $29.5(20.1-38.2) *$ & $28.1(22.1-37.9)$ * & 0.096 \\
\hline Cigarette, n (\%) & $7(18.4)$ & $11(28.9)$ & 0.280 \\
\hline Hypertension, $\mathrm{n}(\%)$ & $8(21.1)$ & $5(13.2)$ & 0.361 \\
\hline Diabetes mellitus, $\mathbf{n}(\%)$ & $2(5)$ & $1(2.5)$ & 0.980 \\
\hline \multicolumn{4}{|l|}{ Drugs, n (\%) } \\
\hline Beta-blocker & $4(10)$ & $5(12.5)$ & 0.943 \\
\hline Metformin & $2(5)$ & $1(2.5)$ & 0.980 \\
\hline Acetil salicylic acid & $4(10)$ & $3(7.5)$ & 0.940 \\
\hline SSRI & $7(17.5)$ & $5(12.5)$ & 0.865 \\
\hline Ejection Fraction (\%) & $60.1(60-62)$ & $61.1(60-68)$ & 0.008 \\
\hline LVEDD (mm) & $42.9 \pm 4.5$ & $41.1 \pm 4.0$ & 0.067 \\
\hline LVESD (mm) & $28.4 \pm 4.6$ & $27.0 \pm 3.1$ & 0.262 \\
\hline IVS (mm) & $10.0(8-12) *$ & $9.4(7-12) *$ & 0.090 \\
\hline PW (mm) & $9.6 \pm 1.4$ & $9.4 \pm 1.4$ & 0.585 \\
\hline
\end{tabular}

BMI: Body mass index, IVS: Interventricular septum, IQR: Interquartile range, LVEDD: Left ventricular end diastolic diameter, LVESD: Left ventricular end systolic diameter SD: Standard deviation, SSRI: Selective serotonin re-uptake inhibitor, PW: Posterior wall.

The (*) sign shows median and interquartile range values.

Table 2. Distribution of baseline laboratory parameters between surgical early menopause and control groups

\begin{tabular}{|c|c|c|c|}
\hline Variable & $\begin{array}{c}\text { Surgical early menopause group }(n=40) \\
\text { Mean } \pm \text { SD } \\
\text { Median }(\text { IQR })^{*}\end{array}$ & $\begin{array}{c}\text { Control group } \\
(n=40) \\
\text { Mean } \pm \text { SD } \\
\text { Median (IQR) * }\end{array}$ & $\begin{array}{c}P \\
\text { value }\end{array}$ \\
\hline Glucose (mg/dl) & $94.7(74-134) *$ & $88.5(75-156)^{*}$ & 0.012 \\
\hline Creatinine (mg/dl) & $0.65 \pm 0.11$ & $0.66 \pm 0.10$ & 0.771 \\
\hline Hemoglobin (gr/dl) & $12.0 \pm 1.2$ & $12.5 \pm 1.2$ & 0.079 \\
\hline White blood cell $\left(10^{3} / \mathrm{ml}\right)$ & $7.4(5.4-10.8) *$ & $6.8(4.8-10.7)^{*}$ & 0.237 \\
\hline Platelete $\left(10^{3} / \mathrm{ml}\right)$ & $271.2 \pm 73.6$ & $260.1 \pm 51.7$ & 0.491 \\
\hline AST (U/L) & $18.6(14-38)$ * & $16.4(12-25)^{*}$ & 0.095 \\
\hline ALT (U/L) & $16.4(9-32)^{*}$ & $13.8(9-40)^{*}$ & 0.013 \\
\hline Total cholesterol (mg/dl) & $191.9 \pm 38.5$ & $174.0 \pm 35.4$ & 0.154 \\
\hline LDL (mg/dl) & $120.2(78.1-180)$ * & $97.3(50-190) *$ & 0.070 \\
\hline HDL (mg/dl) & $58.5(35.2-100) *$ & $56.2(45-76)^{*}$ & 0.135 \\
\hline Triglyceride (mg/dl) & $163.4(55.8-300)$ * & $101.9(50-180) *$ & 0.086 \\
\hline
\end{tabular}

The $\left({ }^{*}\right)$ sign shows median and interquartile range values.

IQR: Interquartile range

\section{Discussion}

In the present study, arterial stiffness parameters were increased in the surgical early menopause patients compared to the healthy controls. To our knowledge, there was no previous research evaluating the influence of surgical early menopause on arterial stiffness and cardiac hemodynamic parameters.

While women are better protected against atherosclerosis during the productive period, yet this effect may change after menopause $(2,9)$. The speed of progression of atherosclerosis increases with menopausal transition and asymptomatic cardiovascular changes often occur in the post-menopausal period $(9,10)$. In the post-menopausal period, deficiency of estrogen and progesterone hormones cause significant changes in lipid and carbohydrate metabolism, thus the atherosclerotic process accelerates, and cardiovascular diseases increase (9-11). This brings about the idea that these effects can be eliminated by hormone replacement therapy and ovarian protective surgical treatment methods may be prevented cardiovascular diseases by maintaining the physiological balance in the body. However, hormone replacement therapy is contraindicated especially hormone sensitive malignant diseases, or it can be considered based on risk to benefit ratio (11). In our study, $67.5 \%$ of patients were operated due to malignancy or a suspicious malignant mass and also other patients did not receive hormone replacement therapy for different reasons.

After natural menopause, the ovaries maintain to produce androgens and other different hormones (12). These androgens are aromatized to estrogens in the adipose tissue. On the other hand, after surgical menopause, the hormone production or peripheral estrogen conversion does not occur due to removal of ovaries (12). For this reason, more changes and high cardiovascular effects are antici- 
pated after the surgical menopause according to the physiological menopause $(12,13)$.

Surgical menopause is appeared to have more effects on the lipid metabolism than physiological menopause and also seen to have higher CAD risk according to the physiological menopause $(12,14)$. However, in a study, the total and LDL cholesterol levels were found to be non-significantly higher after surgical menopause according to the natural menopause (12). In the present study, total cholesterol, LDL cholesterol, and triglyceride levels were found higher in the surgical menopause group, although not statistically significant. But the elevated fasting glucose and AST levels were found statistically significant. The effects of menopause on insulin resistance and carbohydrate metabolism were found consistent with high glucose levels in the present study. However, the deficiency of insulin and HgA1c levels are among the limitations of this study. A meta-analysis demonstrated that surgical early menopause caused the cardiovascular diseases and associated with significantly increased cardiovascular mortality, whereas natural menopause was not had such effects $(15,16)$. The Nurse's Health Study found that women, who underwent bilateral oophorectomy without hormone replacement therapy, have a relatively increased risk of lethal myocardial infarction while those with hormone replacement therapy did not have this increased risk (17). Moreover, the data about the effects of hormone replacement on the cardiovascular system in postmenopausal period are also conflicting. Some prior observational studies showed a preventive effect (18). Conversely, some randomized trials even showed increased cardiovascular risk in women with hormone replacement therapy during the postmenopausal period $(19,20)$.

Table 3. Distribution of arterial stiffness and central hemodynamic parameters between surgical early menopause and control groups

\begin{tabular}{|c|c|c|c|}
\hline Variable & $\begin{array}{l}\text { Surgical early menopause group } \\
\qquad(n=40) \\
\text { Mean } \pm \text { SD } \\
\text { Median (IQR) * }\end{array}$ & $\begin{array}{l}\text { Control group } \\
\quad(n=40) \\
\text { Mean } \pm \text { SD } \\
\text { Median (IQR)* }\end{array}$ & $P$ value \\
\hline Systolic BP (mmHg) & $123.4(95-160)^{*}$ & $119.5(105-165)^{*}$ & 0.107 \\
\hline Diastolic BP (mmHg) & $78.3 \pm 11.0$ & $77.7 \pm 10.2$ & 0.779 \\
\hline Heart Rate (beat/min) & $81.0(70-115)^{*}$ & $73.0(60-100)^{*}$ & 0.008 \\
\hline Mean BP (mmHg) & $99.7 \pm 12.4$ & $96.1 \pm 9.6$ & 0.158 \\
\hline Pulse Pressure (PP) & $45.0(30-68) *$ & $41.7(32-58) *$ & 0.165 \\
\hline cSystolic BP (mmHg) & $114.3 \pm 15.0$ & $110.4 \pm 10.2$ & 0.140 \\
\hline cDiastolic BP (mmHg) & $80.0 \pm 11.0$ & $77.4 \pm 8.5$ & 0.260 \\
\hline Peripheral vascular resistance (PVR) (sec* ${ }^{*} \mathrm{mHg} / \mathrm{ml}$ ) & $1.26(0.7-1.4) *$ & $1.28(1.0-1.4) *$ & 0.966 \\
\hline Cardiac output (CO) (L/min) & $4.87(3.5-6.6) *$ & $4.66(3.9-5.5)^{*}$ & 0.040 \\
\hline Augmentation index (Alx) (\%) & $28.3 \pm 10.9$ & $27.4 \pm 9.0$ & 0.698 \\
\hline Pulse wave velocity (PWV) (m/s) & $6.5(4.8-8.0) *$ & $5.6(4.6-8.7) *$ & $<0.001$ \\
\hline
\end{tabular}

BP: Blood Pressure, c: Central. IQR: Interquartile range.

The $\left(^{*}\right)$ sign shows median and interquartile range values.

Non-invasive assessment of arterial stiffness, a marker of endothelial dysfunction, is used for cardiovascular risk assessment and early diagnosis of vascular injury $(3,21)$. The PWV has been suggested as the gold standard method for the evaluation of arterial stiffness. The Alx is also related to increased aging and blood pressure $(3,21)$. The increase in PWV shows arterial stiffening as a consequence of organic and functional changes in the vessel circulation (10). In a study that PWV was increased in postmenopausal women and was associated with death due to coronary artery disease and stroke in the following 10 - 12 years (22). In another study showed that the PWV was increased in the early postmenopausal period and suggested that this increasing was related to estrogen deficiency and postmenopausal increased cardiovascular diseases (23). The mechanical changes in the vascular wall due to estrogen deficiency may take longer than the deterioration of endothelial function (10). The menopause accelerates the age related increased arterial stiffness (24). However, it is not well known how premenopausal ovariectomy influences the PWV value. There was no important variation observed in the PWV values surgical early menopausal group in some studies. In a study, although a decline in the flowmediated vasodilatation was noticed one week after ovariectomy, there were no important changes in the arterial

stiffness one year after ovariectomy $(25,26)$. In our study, although the PWV was significantly higher in surgical early menopause patients, there was no statistically significant difference in terms of

Although most of the literature data reported an increased risk of women after surgical early menopause, some other data refused these results. In the observational study of the Women's Health Initiative, researchers reported that baseline CAD risk factors were worse in patients who had previously hysterectomy/oophorectomy; and which were the responsible for subsequent CVD conditions, these were the risk factors, not the oophorectomy $(17,26,27)$. The obvious objections to the results of these studies were higher ratio of myocardial infarction (MI), stroke, deep vein thrombosis and congestive heart failure at the baseline of their study (but not before the hysterectomy/oophorectomy); on the other hand, the waist circumference, $\mathrm{BMI}$, blood pressure and cholesterol levels were high before the hysterectomy or oophorectomy. These results 
showed the negative CVD impact of the hysterectomy/oophorectomy performed years ago. A negative effect of prior hysterectomy/oophorectomy was already present at the baseline and this negative effect continued throughout the study $(17,26)$. In the present study, the PWV was found significantly high in the surgical early menopause group compared to the control group, although there were no important variations in terms of risk factors. There is an increasing number of evidence that the deficiency of ovarian function before the time of physiological menopause is associated with a series of adverse outcomes. Surgical early menopause is associated with an increasing risk of menopausal symptoms, sexual dysfunction, early death, CVD, dementia, Parkinsonism, bone loss and osteoporosis. When planned the bilateral oophorectomy, these possible adverse results should be cautiously evaluated towards the possible advantages $(2,13,17,26)$. In our study, arterial stiffness and cardiovascular hemodynamic parameters were evaluated with oscillometric measurement method (Mobil-O-Graph NG (IEM GmbH, Stolberg, Germany) 24-hour ambulatory blood pressure monitor arteriography). The validation of the device and this method has been shown in the many previous studies (6-8). It is accepted as non-invasive, rapid, easy, cheap and the best reproducible method for assessment of large arterial stiffness (6-8). Considering the findings of this study, this method may help in defining the future cardiovascular risks in the surgical early menopause patients.

\section{Study Limitations}

The major limitation of this study that the estradiol level could not be measured. The cross-sectional design of our study was unable to evaluate the longitudinal relations and differentiate causality among arterial stiffness and surgical early menopause. In addition, some patients in the surgical early menopause group had previously received short-term hormone replacement therapy, but there was no history of drug use for the last one year. The operator dependent echocardiographic evaluation is another limitation of the study. The number of patients is limited in the study and therefore the results must be supported with large, randomized trials.

\section{Conclusion}

Arterial stiffness was observed to be significantly increased in surgical early menopause patients compared with healthy subjects independent of other risk factors. The long-term clinical significance of this effect and its relationship with atherosclerotic diseases should be investigated with prospective studies.

Ethical Approval: The protocol was accepted by the ethics committee of the Faculty of Medicine, Ondokuz Mayis University (dATE:28/12/2017) No: 2017/455) and adhered to the Declaration of Helsinki.

Author Contributions:

Concept: M.A, H.U, Ö.G

Literature Review: M.A, M.Ç, Ö.G, Ö.Y
Design : M.A, H.U, Ö.G

Data acquisition: M.A, M.C,, H.U, Ö.G

Analysis and interpretation: M.A, M.Ç, H.U.

Writing manuscript: M.A.

Critical revision of manuscript: M.A, Ö.Y., M.C..

Conflict of Interest: There are no conflicts of interest to declare. All authors have participated in the work and could publicly defend its contents and have read the manuscript prior to its submission for publication and agree with its contents.

Financial Disclosure: Authors declared no financial support.

\section{References}

1. Siniscalchi M, De Franciscis P, Palomba S, Di Palo C, Colacurci N, Nappi C, et al. Effects of surgical menopause and estrogen replacement therapy on atrio-ventricular conduction and ventricular repolarization. Maturitas. 2001; 40(1): 47-51.

2. Cabrera-Rego JO, Navarro-Despaigne $D$, Staroushik-Morel L, Díaz-Reyes K, Lima-Martínez MM, lacobellis G. Association between endothelial dysfunction, epicardial fat and sub-clinical atherosclerosis during menopause. Clin Investig Arterioscler. 2018; 30(1): 21-7.

3. Oliver JJ, Webb DJ. Noninvasive Assessment of Arterial Stiffness and Risk of Atherosclerotic Events. Arterioscler Thromb Vasc Biol. 2003; 23(4): 554-66.

4. Laurent S, Cockcroft J, Van Bortel L, Boutouyrie P, Giannattasio C, Hayoz D, et al. Expert consensus document on arterial stiffness: methodological issues and clinical applications. Eur Heart J. 2006; 27(21): 2588-2605.

5. Sünbül $M$, Çinçin $A$, Bozbay $M$, Mammadov $C$, Ataş $H$, Özşenel EB, et al. Arterial stiffness parameters associated with vitamin $D$ deficiency and supplementation in patients with normal cardiac functions. Turk Kardiyol Dern Ars. 2016; 44(4): 281-8.

6. Hametner B, Wassertheurer S, Kropf J, Mayer C, Eber B, Weber T. Oscillometric estimation of aortic pulse wave velocity: comparison with intra-aortic catheter measurements. Blood Press Monit. 2013; 18(3): 173-6.

7. Franssen PM, Imholz BP. Evaluation of the Mobil-O-Graph new generation ABPM device using the ESH criteria. Blood Press Monit. 2010; 15(4): 229-31.

8. Weiss W, Gohlisch C, Harsch-Gladisch C, Tölle M, Zidek W, van der Giet M. Oscillometric estimation of central blood pressure: validation of the Mobil-O-Graph in comparison with the SphygmoCor device. Blood Press Monit. 2012; 17(3): 128-31.

9. Sari N, Engin-Ustun Y, Kiyak Çağlayan E, Göçmen AY, Polat MF. Evaluation of cardiovascular disease risk in women with surgically induced menopause. Gynecol Endocrinol. 2016; 32(6): 498-501.

10. Yoshida T, Takahashi K, Yamatani H, Takata K, Kurachi H. Impact of surgical menopause on lipid and bone metabolism. Climacteric. 2011; 14(4): 445-52.

11. Kodaman PH. Early menopause: primary ovarian insufficiency and surgical menopause. Semin Reprod Med. 2010; 28(5): 360-69.

12. Verhoeven MO, van der Mooren MJ, Teerlink T, Verheijen RHM, Scheffer PG, Kenemans P. The influence of physiological and surgical menopause on coronary heart disease risk markers. Menopause. 2009; 16(1): 37-49.

13. Appiah D, Schreiner PJ, Bower JK, Sternfeld B, Lewis CE, Wellons MF. Is Surgical Menopause Associated with Future 
Levels of Cardiovascular Risk Factor Independent of Antecedent Levels? The CARDIA Study. Am J Epidemiol. 2015; 182(12): 991-9.

14. Tuna V, Alkiş I, Safiye AS, Imamoglu N, Bayram N, Ali Ismet T. Variations in blood lipid profile, thrombotic system, arterial elasticity and psychosexual parameters in the cases of surgical and natural menopause. Aust N Z J Obstet Gynaecol. 2010; 50(2): 194-9.

15. Atsma F, Bartelink MLEL, Grobbee DE, Van der Schouw YT. Postmenopausal status and early menopause as independent risk factors for cardiovascular disease: a meta-analysis. Menopause. 2006; 13: 265-79.

16. Lobo RA. Surgical menopause and cardiovascular risks. Menopause 2007; 14: 562-6.

17. Rodriguez $M$, Shoupe D. Surgical menopause. Endocrinol Metab Clin North Am. 2015; 44(3): 531-42.

18. Grodstein F, Manson JE, Colditz GA, Willett WC, Speizer FE, Stampfer MJ. A prospective, observational study of postmenopausal hormone therapy and primary prevention of cardiovascular disease. Ann Intern Med. 2000; 133: 933-41.

19. Prentice RL, Manson JE, Langer RD, Anderson GL, Pettinger $\mathrm{M}$, Jackson RD, et al. Benefits and risks of postmenopausal hormone therapy when it is initiated soon after menopause. Am J Epidemiol. 2009; 170: 12-23.

20. Rossouw JE, Anderson GL, Prentice RL, LaCroix AZ, Kooperberg $C$, Stefanick $M L$, et al. Risks and benefits of estrogen plus progestin in healthy postmenopausal women: principal results From the Women's Health Initiative randomized controlled trial. JAMA. 2002; 288: 321-33.

21. Oylumlu $M$, Yuksel M, Yildiz A, Bilik MZ, Akil MA, Ozler A, et al. A simple method for the assessment of arterial stiffness in pre-eclamptic patients. Clin Exp Hypertens. 2014; 36(8): 531-7.

22. Lebrun $C E$, van der Schouw $Y T$, Bak AA, de Jong FH, Pols HA, Grobbee $D E$, et al. Arterial stiffness in postmenopausal women: determinants of pulse wave velocity. J Hypertens. 2002; 20(11): 2165-72.

23. Zaydun $G$, Tomiyama $H$, Hashimoto $H$, Arai $T$, Koji $Y$, Yambe $M$, et al. Menopause is an independent factor augmenting the age-related increase in arterial stiffness in the early phase. Atheosclerosis. 2006; 184(1): 137-42.

24. Takahashi K, Miura S, Mori-Abe A, Kawagoe J, Takata K, Ohmichi $M$, et al. Impact of menopause on the augmentation of arterial stiffness with aging. Gynecol Obstet Invest. 2005; 60: 162-6.

25. Ohmichi M, Kanda Y, Hisamoto K, Morishige K, Takahashi K, Sawada K, et al. Rapid changes of flow-mediated dilatation after surgical menopause. Maturitas. 2003; 44: 125-31.

26. Gavin KM, Jankowski C, Kohrt WM, Stauffer BL, Seals DR, Moreau KL. Hysterectomy is associated with large artery stiffening in estrogen-deficient postmenopausal women. Menopause. 2012; 19(9): 1000-7.

27. Mack WJ, Slater CC, Xiang M, Shoupe D, Lobo RA, Hodis HN. Elevated subclinical atherosclerosis associated with oophorectomy related to time since menopause rather than type of menopause. Fertil Steril. 2004; 82(2): 391-7. 